\title{
ANALISIS STRUKTURALISME GENETIK DAN NILAI KARAKTER NOVEL MARYAM KARYA OKKY MADASARI SEBAGAI BAHAN AJAR SASTRA DI SEKOLAH MENENGAH ATAS
}

\author{
Laeli Rohmawati Dewi, Muhammad Rohmadi, Raheni Suhita \\ Universitas Sebelas Maret \\ E-mail: laelyrahmawati95@gmail.com
}

\begin{abstract}
Abstrak: Penelitian ini bertujuan untuk mendeskripsikan 1) unsur intrinsik novel Maryam karya Okky Madasari; (2) pandangan dunia pengarang; (3) nilai pendidikan karakter dalam novel Maryam; dan (4) relevansi novel Maryam sebagai bahan ajar sastra di SMA. Penelitian ini menerapkan metode kualitatif dengan pendekatan strukturalisme genetik. Data dan sumber data yang digunakan dalam penelitian ini adalah arsip/dokumen dan informan. Teknik pengambilan subjek penelitian yang digunakan adalah purposive sampling. Teknik pengumpulan data dilakukan dengan analisis dokumen dan wawancara mendalam. Validitas data yang digunakan adalah triangulasi teori dan triangulasi sumber. Teknik analisis data dilakukan dengan teknik analisis mengalir. Hasil penelitian yakni, (1) ada keterjalinan antarunsur intrinsik novel Maryam meliputi tema, tokoh dan penokohan, alur/plot, latar/setting, sudut pandang, dan amanat; (2) pandangan dunia pengarang meliputi pandangan religi, humanisme, dan feminisme; (3) cerita dalam novel Maryam mengandung 10 nilai pendidikan karakter meliputi religius, toleransi, kerja keras, mandiri, demokratis, rasa ingin tahu, bersahabat/komunikatif, peduli sosial, dan tanggung jawab; (4) novel Maryam relevan dijadikan bahan ajar sastra di SMA khususnya pada KD (3.8)Menafsir pandangan pengarang terhadap kehidupan dalam novel yang dibaca dan (3.9)Menganalisis isi dan kebahasaan novel.
\end{abstract}

Kata kunci: novel, unsur intrinsik, strukturalisme genetik, nilai pendidikan karakter, bahan ajar sastra

\section{GENETIC STRUCTURALISM AND CHARACTER VALUE ANALYSIS OF “MARYAM" NOVEL BY OKKY MADASARI AS LITERATURE LEARNING MATERIAL IN SENIOR HIGH SCHOOL}

\begin{abstract}
This study aims to describe the intrinsic elements of the novel 1) Maryam by Okky Madasari; (2) the author's view of the world; (3) the value of character education in the novel of Maryam; and (4) the relevance of the novel of Maryam as the materials literature in high school. The research of applying qualitative methods with genetic structuralism approach. Data and data sources this research is the archives/documents and informants. Research subject retrieval technique used the purposive sampling. The technique of data collection used the analysis of documents and in-depth interviews. The validity of the data used triangulation theory and sources. Data analysis technique used analysis of the flow.Results of the study are: (1) there is relationship between substance of the novel of Maryam includes themes, characters and characterization, setting, plot, point of view, and value; (2) the author's world view includes the religious view, humanism, and feminism; (3) the story in the novel of Maryam contains 10 values character education includes religious tolerance, hard working, independent, democratic, curiosity, friendly/communicative, social care, and responsibility; (4) the novel Maryam relevant with learning materials of literature in high school especially in $K D$ (3.8) Interpret the author's view on life in the novel is read and Analyze (3.9) and linguistic content of the novel.
\end{abstract}

Keywords: novel, elements of intrinsic, genetic structuralism, the value of character education, literary materials.

BASASTRA Jurnal Bahasa, Sastra, dan Pengajarannya

Volume 8 Nomor 1, April 2020, P-ISSN 2302-6405, E-ISSN 2714-9765 


\section{PENDAHULUAN}

Karya sastra adalah karya yang berupa tulisan maupun lisan dengan wahana bahasa untuk mengekspresikan pengalaman dan pikiran sebagai tujuan estetika. Objek karya sastra adalah realitas kehidupan. Ide yang dituangkan dalam sastra menggambarkan fenomenafenomena kehidupan masyarakat yang mencirikan sejarah, lingkungan, dan perisitiwa pada zamannya. Pembaca setidaknya akan tahu bagaimana kondisi sosial masyarakat pada masa itu meskipun tidak selalu digambarkan persis apa adanya. Rokhmansyah (2014:2) mengatakan bahwa sastra sebagai produk budaya manusia berisi nilai-nilai yang hidup dan berlaku dalam masyarakat.

Fungsi hakikat sebuah karya sastra: dulce et utile, yang berarti menyenangkandan berguna. Karya sastra bukan menjadi bahan bacaan yang menghibur saja melainkan mengandung nilai-nilai edukasi yang dapat diteladani. Karya sastra yang bernilai adalah karya sastra yang banyak mengandung pesanpesan baik yang dapat dicontoh. Pesanpesan tersebut diharapkan mampu membentuk karakter atau kepribadian pembaca. Salah satu contoh karya sastra di Indonesia adalah novel. Novel merupakan karya sastra dalam bentuk tulis yang mengisahkan rangkaian panjang kehidupan seseorang yang digambarkan oleh karakter setiap tokoh. Kosasih (2014:60) mengungkapkan bahwa novel adalah karya imajinatif yang mengisahkan sisi utuh atas problematika kehidupan seseorang atau beberapa orang tokoh.

Penelitian dalam bidang sastra kini telah berkembang. Pendekatan dalam penelitian ini yaitu strukturalisme genetik. Jabrohim (2014:79-80) mengatakan bahwa pencetus Strukturalisme Genetik dalah Lucien Goldman, seorang ahli sastra Perancis. Pendekatan ini merupakan satusatunya pendekatan yang mampu merekontruksikan pandangan dunia pengarang. Genetik sastra artinya asal-usul karya sastra. Adapun faktor yang terkait dengan asal-usul karya sastra adalah pengarang dan kenyataan sejarah yang turut mengkondisikan karya sastra saat diciptakan. Ranah pendekatan strukturalisme genetik menganggap bahwa karya sastra perlu dikaji secara totalitas dari unsur dalam maupun luar karya sastra yang saling berkaitan erat sehingga membentuk satu kesatuan utuh. Unsurunsur tersebut dibagi atas unsur intrinsik dan unsur ekstrinsik.

Memang pada kenyatannya, latar belakang penciptaan karya sastra masih sering diabaikan, padahal hal ini merupakan faktor yang sangat penting dalam memahami nilai estetik yang juga berfungsi sebagai sarana pembentukan karakter peserta didik. Hunter (dalam Hasanah, 2012:42) mengatakan bahwa pengertian karakter ialah perpaduan tiga elemen moral yaitu disiplin moral, kelekatan moral dan otonomi moral. Karakter seseorang dikonstruksi dari ketiga elemen moral tersebut yang dipengaruhi bukan hanya oleh perbedaan individual dalam memahami dan mengetahui makna serta aturan moral tetapi juga dipengaruhi oleh perbedaan faktor sosial budaya yang mempengaruhi individu.

Novel dikenalkan dalam dunia pendidikan sebagai bahan apresiasi sastra yang memiliki nilai unggul. Artinya, kandungan cerita yang mengangkat kenyataan sosial dan problematika kehidupan dapat dijadikan bahan kajian pembelajaran. Novel tidak hanya menampilkan sebuah cerita yang menghibur tetapi berguna dalam pembentukan karakter. Pembelajaran sastra dapat dijadikan kepada peserta didik. Samani dan Hariyanto (2012:46) mengungkapkan bahwa pendidikan karakter adalah proses pemberian tuntunan kepada peserta didik untuk menjadi manusia seutuhnya yang berkarakter dalam dimensi hati, pikir, raga, serta rasa, dan karsa Guru dalam melakukan pembelajaran di kelas membutuhkan bahan ajar yang sesuai dengan tuntutan kurikum. 
Bahan ajar berkedudukan sebagai modal awal yang akan digunakan atau diproses untuk mencapai hasil. Hasil tersebut berupa pemahaman dan kemampuan peserta didik. Bahan ajar yang baik harus memenuhi kriteria bahan ajar dan memiliki integritas dengan realitas kehidupan. Wismanto (2013:4) mengemukakan bahwa bahan ajar atau isi pendidikan adalah segala sesuatu yang oleh guru diberikan kepada peserta didik yang secara garis besar berisi pengetahuan, keterampilan, dan sikap yang harus dipelajari siswa sehingga diharapkan dapat dikuasai siswa dalam rangka mencapai standar kompetensi yang telah ditentukan. Apabila dilihat kaitan antara novel dan pengajaran, novel menjadi salah satu jenis karya sastra yang dapat dijadikan bahan ajar apresiasi sastra di sekolah. Begitu pula bahan ajar dapat diperoleh dari sebuah novel. menurut jurnal penelitian Khofiyana, Suyitno, dan Kunddharu (2014:448-462) yang berjudul Pengembangan Bahan Ajar Membaca Biografi di SMA Melalui Analisis Novel Biografi Sepatu Dahlan bahwa pemilihan bahan ajar hendaknya mampu menanamkan nilai-nilai pendidikan sosial dan budaya, memiliki kecakapan bahasa yang mudah dipahami serta sesuai dengan perkembangan psikologi peserta didik. Analisis mengenai nilai pendidikan karakter dalam novel dapat membantu peserta didik dan guru untuk menunjang karakter yang dapat diterapkan di sekolah dan masyarakat. Pemahaman nilai pendidikan karakter dalam novel perlahanlahan akan mempengaruhi karakter peserta didik.

Novel Maryam karya Okky Madasari merupakan salah satu novel Indonesia yang popular karena telah meraih penghargaan Anugerah Khatulistiwa Literary Award pada tahun 2012. Novel Maryam karya Okky Madasari dipilih bukan karena unsur estetikanya saja, melainkan karena banyak mengandung nilai-nilai kehidupan yang dapat diteladani.
Berdasarkan uraian di atas, dapat disimpulkan bahwa dalam novel Maryam karya Okky Madasari tidak hanya menyajikan nilai estetik saja, melainkan terdapat nilai-nilai pendidikan karakter yang dapat diteladani peserta didik. Berangkat dari gagasan tersebut, peneliti tertarik untuk mengkaji novel Maryam Okky Madasari dengan pendekatan strukturalisme genetik dan dianalisis nilai pendidikan karakternya. Selain itu, novel Maryam karya Okky Madasari diyakini dapat menjadi bahan ajar yang relevan dalam pembelajaran sastra di SMA kurikulum 2013 dengan kompetensi dasar (3.8)Menafsir pandangan pengarang terhadap kehidupan dalam novel yang dibaca dan kompetensi dasar (3.9)Menganalisis isi dan kebahasaan novel. Penelitian ini berjudul: Analisis Strukturalisme Genetik dan Nilai Pendidikan Karakter Novel Maryam karya Okky Madasari sebagai Bahan Ajar Sastra di Sekolah Menengah Atas.

\section{METODE PENELITIAN}

Penelitian ini berlangsung selama enam bulan dimulai pada bulan Desember hingga bulan Mei 2017. Metode penelitian yang digunakan adalah metode kualitatif dengan pendekatan analisis dokumen (content analysis) pada novel Maryam karya Okky Madasari. Menurut Bogdan dan Taylor (dalam Moleong, 2012:4) "Penelitian kualitatif adalah prosedur penelitian yang menghasilkan data deskripsif berupa kata-kata tertulis dari orang-orang dan perilaku yang dapat diamati." Data dan sumber data yang digunakan adalah teks novel Maryam dan teks (transkrip wawancara) kepada pengarang novel Maryam, guru, dan siswa SMA Negeri 1 Gemolong. Pemilihan subjek penelitian dilakukan dengan teknik purposive sampling. Menurut Muhajir (2000:64), purposive sampling merupakan pemilihan sampel yang disesuaikan dengan masalah, kebutuhan dan kemantapan peneliti dalam memperoleh data Data dikumpulkan dengan teknik analisis 
dokumen dan wawancara. Data yang dapat diuji validitasnya dengan teknik uji validitas teori dan sumber. Teknik analisis data dalam penelitian ini menggunakan teknik analisis mengalir yang dikemukakan oleh Miles dan Huberman.

\section{HASIL DAN PEMBAHASAN}

\section{Unsur Intrinsik Novel Maryam Karya Okky Madasari}

Struktur novel yang akan diteliti meliputi tema, tokoh dan penokohan, alur/plot, latar/setting, sudut pandang, dan amanat.

\section{Tema}

Tema adalah awal mula dibentuknya cerita, kemudian diikuti oleh unsur lain dalam tahap membangun sebuah cerita. Wahyuningtyas dan Santoso (2011:3) memberikan pengertian bahwa tema adalah gagasan utama atau gagasan sentral pada sebuah cerita atau karya sastra. Wirajaya dan Sudarmawarti (2008:15) mengatakan bahwa tema merupakan gagasan pokok yang mendasari terbentuknya cerita. Tema yang diangkat dalam novel Maryam karya Okky Madasari ini mengangkat persoalan diskriminasi yang dialami kaum Ahmadiyah. Pertentangan dan bahkan pengusiran terhadap kaum Ahmadiyah membuat hidup mereka kehilangan hak untuk hidup damai dan layak.

\section{Tokoh dan Penokohan}

Penentuan tokoh dapat dilihat dari peran dalam cerita. Kosasih (2003:270) mengungkapkan bahwa tokoh dibagi atas tiga golongan yaitu (1) tokoh protagonis; yaitu tokoh yang mendukung jalannya cerita; (2) tokoh antagonis, yaitu tokoh penentang cerita; dan (3) tokoh tritagonis, yaitu tokoh pembantu baik untuk tokoh protagonis maupun untuk tokoh antagonis. Keseluruhan tokoh yang terdapat di dalam novel berjumlah dua belas yang meliputi Maryam, Umar, Pak Khairuddi, Zulkhair, Gamal, Alam, Ibu Alam, Pak RT Rohmat, Pak haji, Gubernur, Tuan Guru Ahmad Rizqi, dan polisi. Tokoh digambarkan menjadi tokoh protagonis, antagonis, dan tritagonis.

Alur/Plot

Alur merupakan rangkaian peristiwa atau kejadian yang terjadi di dalam cerita. Wirajaya dan Sudarmawarti (2008:15) mengartikan alur sebagai rangkaian peristiwa yang merupakan jalinan konflik antartokoh yang berlawanan. Alur yang digunakan oleh pengarang dalam menyampaikan ceritanya menggunakan alur campuran, namun tahapan alur bergerak lurus mulai dari (1) tahap penyituasian atau tahap situation; (2) tahap pemunculan konflik atau tahap generating circumstances; (3) tahap peningkatan konflik atau tahap rising action; (4) tahap klimaks atau tahap klimax; dan (5) tahap penyelesaian atau tahap denouement.

\section{Latar/Setting}

Menurut pendapat Stanton (2007:35) latar adalah lingkungan yang melingkupi sebuah peristiwa dalam cerita, semesta yang berinteraksi dengan peristiwaperistiwa yang sedang berlangsung. Novel Maryam memuat tiga kategori latar, yakni latar tempat, waktu, dan sosial. Pertama, setting tempat dalam novel Maryam meliputi Lombok, Gegerung, Gerupuk, dan Gedung Transito. Kedua, setting waktu terjadi pada tahun 1993, 1997, 2000, 2001, 2005, 2008, dan 2011. Ketiga, setting sosial meliputi kebiasaan hidup, adat istiadat, tradisi, keyakinan, cara berfikir dan bersikap, dan pandangan hidup.

\section{Sudut Pandang}

Kosasih (2014:69) memposisikan pengarang dalam membawakan cerita atas dua macam, yaitu (1) berperan langsung sebagai orang pertama; dan (2) hanya sebagai orang ketiga yang berperan sebagai pengamat. Sudut pandang yang digunakan dalam cerita yaitu orang ketiga serba tahu. Hal ini dapat dilihat dari penggunaan nama Maryam, Gamal, Umar, Alam, dan tokoh-tokoh lain sebagai narator cerita. Selain itu, narator juga menggunakan kata Ia dan mereka. 


\section{Amanat}

Kosasih (2014:137) mengatakan bahwa amanat tersimpan rapi dan disembunyikan pengarangnya dalam keseluruhan cerita. Beberapa amanat yang terkandung dalam novel Maryam meliputi sikap saling menghargai, bertoleransi, peduli sesama, dan tidak bersikap sewenang-wenang.

\section{Pandangan Dunia Pengarang}

Pandangan dunia pengarang mengenai karya sastra yang diciptakan merupakan sebuah gagasan pemikirannya terhadap fenomena sosial di masyarakat. Sekelompok manusia mempunyai latar belakang sosial dan ekonomi yang sama, cara-cara untuk membangun keseimbangan lingkungannya juga sama. Kerekatan hubungan antaranggota membentuk suatu kelas sosial tertentu yang membedakan dengan kelas sosial yang lain. Hal ini yang memengaruhi pandangan pengarang dalam penciptaan karya sastra. Berkaitan dengan pengertian pandangan dunia, Wardani (2009:49) mengemukakan "Pandangan dunia merupakan kesadaran kolektif atau kesadaran kelompok muncul sebagai reaksi terhadap situasi ekonomi dan sosial tententu yang menimbulkan serangkaian aktivitas penciptaan karya sastra oleh pengarang....". Pandangan dunia pengarang dalam novel Maryam karya Okky Madasari meliputi deskripsi kepengarangan Okky Madasari, pandangan dunia religi, humanisme, liberal, dan feminisme. Deskripsi kepengarangan Okky Madasari yang memiliki latar belakang seorang jurnalistik yang berusaha mengangkat isu-isu sosial di masyarakat Indonesia. Pandangan religi dimunculkan dalam penulisan novel Maryam setelah ia mencoba menggali kehidupan penganut Ahmadi yang sangat menderita. Okky Madasari ini tidak melakukan pemihakan atau sebagai provokator, sebagai seorang muslim Okky Madasari menyadari bahwa ia peduli terhadap makhluk sesamanya. Hal ini berarti pengarang juga memiliki pandangan humanisme, artinya pengarang mempedulikan isu-isu yang dialami manusia sebagai makhluk sosialnya. Selain itu, pandangan feminisme menyoroti tokoh utama Maryam sebagai wanita tangguh dengan segala beban yang dialami kehidupannya sebagai seorang Ahmadi.

\section{Nilai Pendidikan Karakter}

Menurut pendapat Kusuma (dalam Pristine dan Suryani, 2015:83) mengemukakan bahwa pendidikan karakter merupakan bentuk kegiatan manusia yang di dalamnya terdapat suatu tindakan yang mendidik dan diperuntukkan bagi generasi selanjutnya. Tujuan pendidikan karakter adalah untuk membentuk penyempurnaan diri individu secara terus-menerus dan melatih kemampuan diri demi menuju ke arah hidup yang lebih baik.

Novel Maryam karya Okky Madasari memuat sepuluh nilai pendidikan karakter, yaitu nilai religius, jujur, kerja keras, mandiri, demokratis, rasa ingin tahu, bersahabat/komunikatif, peduli sosial, dan tanggung jawab.

\section{Relevansi Novel Maryam sebagai Bahan Ajar Sastra di SMA}

Pada kurikulum 2013 untuk Sekolah Menengah Atas terdapat Kompetensi Inti dan Kompetensi Dasar yang berkaitan dengan pembelajaran novel. Kompetensi Dasar tersebut yakni (3.8) Menafsir pandangan pengarang terhadap kehidupan dalam novel yang dibaca dan (3.9) Menganalisis isi dan kebahasaan novel. Novel Maryam karya Okky Madasari merupakan novel yang layak untuk dijadikan bahan ajar sastra di kelas XII SMA sesuai kurikulum 2013. Hal ini karena novel tersebut memuat beberapa aspek di antaranya bahasa yang mudah dipahami, unsur intrinsik mudah dikaji, mengajarkan peserta didik untuk menggali lebih dalam pandangan dunia pengarang terhadap novel dan memuat nilai pendidikan karakter. Kisah kehidupan dalam novel Maryam dapat dijadikan refleksi diri terhadap isu-isu sosial yang 
terjadi di Indonesia. Selain itu, konflik dalam cerita mengajarkan peserta didik untuk dapat menghargai adanya perbedaan di masyarakat. Menurut informan Okky Madasari selaku penulis novel Maryam mengemukakan bahwa novel tersebut mengangkat tema yang bagus sesuai dengan kenyataan sosial di masyarakat. Selain itu, novel tersebut juga mengandung nilai-nilai moral yang dapat diteladani peserta didik.

Menurut Djamarah dan Zain (2014:44), aktivitas anak didik akan berkurang bila bahan ajar yang diberikan oleh guru tidak atau kurang menarik perhatian mereka. Novel Maryam karya Okky Madasari dapat digunakan sebagai bahan ajar di SMA karena menggunakan pemilihan bahasa yang popular dan mendayu-dayu saat menampilkan episode kisah hubungannya dengan Alam dan Gamal. Kejiwaan dan dan pembentukan karakter yang dibawakan oleh tokoh Maryam juga terbilang sangat bagus karena menampilkan sosok wanita yang tangguh. Dilihat dari segi umurnya, siswa kelas XII memang terarik dengan novel yang berceritakan tentang percintaan dan sosial sehingga novel Maryam dapat menarik perhatian peserta didik.

\section{REFERENSI}

Djamarah, S.B. \& Zain, A. (2014). Strategi Belajar Mengajar. Jakarta: Rineka Cipta.

Kosasih, E. (2003). Ketatabahasaan dan Kesustraan. Bandung: Yrama Widya.

(2014). Dasar-dasar Keterampilan Bersastra. Bandung: Yrama Widya.

Khofiyana, E., Suyitno, \& Saddhono. K. (2014). Pengembangan Bahan Ajar Membaca Biografi di SMA Melalui Analisis Novel Biografi Sepatu Dahlan. Jurnal Basastra, 1 (3), 448462.

Rokhmansyah, A. (2014). Studi dan Pengkajian Sastra: Perkenalan
Berdasarkan ulasan di atas, dapat disimpulkan bahwa, novel Maryam karya Okky Madasari memiliki relevansi sebagai bahan ajar sastra di SMA.

\section{SIMPULAN}

Berdasarkan hasil penelitian ini, dapat disimpulkan bahwa novel Maryam karya Okky Madasari memiliki keterjalinan antarunsur intrinsik yang meliputi tema, tokoh dan penokohan, alur/plot, latar/setting, sudut pandang, dan amanat. Pandangan dunia lain dalam novel meliputi pandangan religi, humanisme, dan feminisme. Ditinjau dari relevansi novel Maryam sebagai bahan ajar sastra di SMA, novel ini sesuai dengan kompetensi dasar yang ada pada silabus Bahasa Indonesia 2013. Selain itu, novel Maryam cocok dijadikan bahan ajar sastra karena sesuai kriteria bahan ajar yang meliputi aspek bahasa, psikologi, sosial dan budaya siswa, dan mengandung nilai pendidikan yang dapat diteladani siswa. Berdasarkan hasil penelitian ini, peneliti menyarankan kepada guru Bahasa Indonesia untuk menggunakan novel Maryam karya Okky Madasari sebagai bahan ajar sastra di kelas.
Awal terhadap Ilmu Sastra. Yogjakarta: Graha Ilmu.

Moleong, L.J. (2012). Metodologi Penelitian Kualitatif Edisi Revisi. Bandung: PT Remaja Rosdakarya.

Muhajir, N. (2000). Metode Penelitian Kualitatif. Yogyakarta: Rake Sarasin.

Pristine, D \& Suryani, E. (2015).Implementasi Pembentukan Karakter Budi Pekerti di SMP Negeri 1 Tanggul Jember. Jurnal Kependidikan Karakter,1(1),82-89. http://journal.uny.ac.id/index.php/jp $\mathrm{ka} /$ article/view/8614

Samani, M. \& Hariyanto. (2012). Pendidikan Karakter (Konsep dan 
Model).Bandung: Remaja Jakarta: Pusat Perbukuan Rosdakarya. Departemen Pendidikan Nasional.

Wahyuningtyas, S. \& Santosa, W.H. Wismanto, A. (2013). Pengembangan (2011). Sastra: Teori dan Bahan Ajar Bermuatan Budi Pekerti Implementasi. Surakarta: Yuma pada Pembelajaran Menulis Cerpen Pustaka.

Wardani, N.E. (2009). Makna Totalitas dalam Karya Sastra. Surakarta: Sebelas Maret University Press.

untuk Siswa Kelas IX. Jurnal Sasindo, $\quad 1(1)$. 1-14. http://id.portalgaruda.org/?ref=brow se \&mod=viewarticle $\&$ article $=6948$

Wirajaya, A.S. \& Sudarmawarti. (2008).

Berbahasa dan Bersatra Indonesia. 